\title{
Relação entre a dimensão do campo de jogo e os comportamentos táticos do jogador de futebol
}

CDD. 20.ed. 796.017

796.33

\author{
Israel Teoldo da COSTA* \\ Júlio GARGANTA ${ }^{* * *}$ \\ Pablo J uan GRECO** \\ Isabel MESQUITA*** \\ Ezequiel MULLER ${ }^{* * *}$
}

*Universidade Federal de Viçosa.

**Universidade Federal

de Minas Gerais.

***Faculdade de Des-

porto, Universidade do

Porto - Portugal.

\begin{abstract}
Resumo
0 presente trabalho teve por objetivo verificar de que modo os comportamentos táticos dos jogadores de Futebol variam perante a alteração das dimensões do campo de jogo. Para tal, foram avaliadas 1476 ações táticas desempenhadas por 12 jogadores da categoria sub-15. 0 instrumento utilizado para a recolha e a análise dos dados foi o Teste "GR3-3GR", que permite avaliar as ações táticas desempenhadas por cada um dos jogadores participantes, com e sem bola, de acordo com 10 princípios táticos fundamentais do jogo de Futebol, tendo em conta a localização da ação no campo de jogo e o seu resultado final. A partir dessas informações o teste fornece 13 indices de performance tática do jogador. A análise estatística foi realizada com recurso ao SPSS for Windows, a partir da análise exploratória verificou-se a normalidade da distribuição, aplicando-se também o teste de Shapiro-Wilk, teste de qui-quadrado, teste de MannWhitney $U(p \leq 0,05)$ e teste de fiabilidade. Os resultados mostraram 26 diferenças significativas entre as 76 variáveis analisadas nesse estudo. Destas, 21 demonstraram valores superiores no Campo Menor e somente cinco no Campo Maior. Conclui-se que os comportamentos desempenhados pelos jogadores de Futebol foram influenciados pelas alterações nas dimensões do campo de jogo, principalmente no que concerne a organização defensiva das equipes.
\end{abstract}

Unitermos: Futebol; Princípios táticos; Jogos reduzidos; Avaliação; Tática.

\section{Introdução}

No jogo de Futebol as capacidades táticas e os processos cognitivos subjacentes à tomada de decisão são considerados requisitos essenciais para a excelência do desempenho esportivo (MCPHERSON, 1994). Tal premissa se fortalece considerando três constrangimentos específicos do jogo: 1) a maioria das ações ocorre sem que os praticantes estejam em contato direto com a bola; 2) praticantes com limitado domínio das habilidades técnicas são capazes de jogar se tiverem um nível razoável de compreensão tática (OsLin, Mitchell \& Griffin, 1998; Tavares, 1993; Tavares, Greco \& GARGANTA, 2006); 3) parco conhecimento tático pode comprometer o uso oportuno e ajustado das habilidades técnicas (Mesquita, GraÇA, Gomes \& Cruz, 2005).

Tal perspectiva da tática confere um destaque especial às movimentações dos jogadores e ao respectivo posicionamento no campo, que se refletem na capacidade de ocuparem e/ou criarem espaços livres em função dos princípios táticos adequados aos diferentes momentos do jogo. Os princípios táticos configuram um conjunto de normas sobre o saberfazer no jogo e, portanto, proporcionam aos jogadores a possibilidade de conseguirem soluções táticas eficazes para os problemas decorrentes das situações que defrontam (GARGANTA \& PINTO, 1994). Uma vez entendidos e adotados pelos jogadores, os princípios táticos auxiliam a equipe no melhor controle do jogo, na qualidade da posse de bola, na gestão do ritmo de jogo, nas tarefas defensivas, nas transiçōes entre fases, no alcance mais fácil do gol, etc. (COSTA, GARGANTA, Greco \& MesQuiTA, 2009c). Tal não significa que o domínio técnico seja descurado, na fomação 
dos praticantes, dada a relação de dependência perene entre tomar decisōes apropriadas (tática) e a capacidade de operacionalizá-las (técnica), a qual é concorrente do incremento de desempenho em competição (ARaúJo, DaVIDS \& HRISTOVSKI, 2006; MESQuitA, 2005). Todavia, e apesar de constituírem duas faces da mesma moeda (MEsQuita, 2005), sendo que o treinamento de jovens praticantes deve de forma sistemática atender às duas vertentes, o domínio tático deve assumir primazia na medida em que quanto mais ajustada e qualificada for a aplicação dos princípios táticos, melhores condições se criam para os praticantes tomarem decisōes apropriadas, sem as quais as execuções técnicas perdem todo o sentido e significado.

Uma das formas de propiciar o desenvolvimento desses princípios e as competências táticas de jogo é alterar durante o processo de ensino e treino a estrutura formal e funcional do jogo (LEE \& WARD, 2009). Através dessas alterações pode-se manipular didaticamente a complexidade do jogo de acordo com o conhecimento tático e o nível de desempenho do praticante (MESQUITA, 2006). Isso acontece quando o treinador ou professor modifica a estrutura ou o conteúdo dos exercícios para facilitar o fluxo de jogo ou para induzir a ocorrência de ações relacionadas com as capacidades táticas (Holt, Strean \& Bengoechea, 2002).

Entre a gama de modificaçôes que pode ser utilizada na estrutura formal e funcional do jogo no processo de ensino e treino do Futebol, a relacionada com a dimensão do campo é bastante utilizada (Frencken \& Lemmink, 2009; Grant, Williams,

\section{Materiais e métodos}

\section{Amostra e variáveis de estudo}

Foram avaliadas 1.476 ações táticas, 701 das quais ofensivas e 775 defensivas, desempenhadas por jogadores da categoria sub-15 (idades compreendidas entre 14 e 15 anos).

As variáveis independentes do estudo reportam-se às dimensōes do campo de jogo sendo denominadas: Campo Maior (36 m x 27 m) e Campo Menor (27 m $\mathrm{x} 18 \mathrm{~m}$ ). As variáveis dependentes estão agrupadas em duas Macro-categorias: Observação e Produto.
Dodd \& Johnson, 1999; Grant, Williams \& Johnson, 1999; Owen, Twist \& Ford, 2004). Isto acontece porque a alteração no espaço de jogo propicia mudanças no seu fluxo e condiciona as movimentaçōes em campo, refletindo na forma como os jogadores e as equipes defendem/atacam e como usam o espaço de jogo disponível para fazer variar os seus comportamentos (HUGHES \& BARTLETT, 2002; Mesquita et al., 2005).

$\mathrm{Na}$ literatura alguns estudos têm analisado a influência da dimensão do campo sobre os comportamentos dos jogadores, considerando os aspectos fisiológicos e/ou técnicos (GRANT et al., 1999; JEFFREYS, 2004; Jones \& Drust, 2007; Kelly \& Drust, 2009; Owen, Twist \& Ford, 2004; Panter, Johnston, Mullins, Sato, Wells \& McAuley, 2008; Platt, Maxwell, Horn, Williams \& Reilly, 2001; Tessitore, Meeusen, Piacentini, Demarie \& Capranica, 2006). Outros estudos têm avaliado os aspectos táticos, incluindo como variáveis independentes o posicionamento dos jogadores, as diferenças de idade ou o processo de ensino-treino (French, Werner, Rink, Taylor \& Hussey, 1996a; French, Werner, Taylor, Hussey \& Jones, 1996b; Giacomini \& Greco, 2008; Oslin, Mitchell \& Griffin, 1998; Pérez-Morales \& GRECO, 2007). Entretanto, não se conhece nenhum estudo que tenha avaliado as variaçóes dos comportamentos táticos de jogadores de Futebol em função das modificações do espaço de jogo.

Desta forma, o presente trabalho teve por objetivo verificar de que modo os comportamentos táticos dos jogadores de Futebol variam perante a alteração das dimensões do campo de jogo
A Macro-categoria Observação inclui 24 variáveis distribuídas em três categorias: Princípios Táticos, Localização da Ação no Campo de Jogo, Resultado da Ação. Já a Macro-categoria Produto compōe-se de 52 variáveis dispostas em quatro categorias: Indice de Performance Tática - IPT, Açôes Táticas, Percentual de Erros e Localização da Ação Relativa aos Princípios - LARP (vide FIGURA 1). Esta última categoria corresponde à realização das açôes táticas relativas aos princípios ofensivos no meio campo defensivo e de açóes táticas relativas aos princípios defensivos no meio campo ofensivo. 
Variáveis Independentes

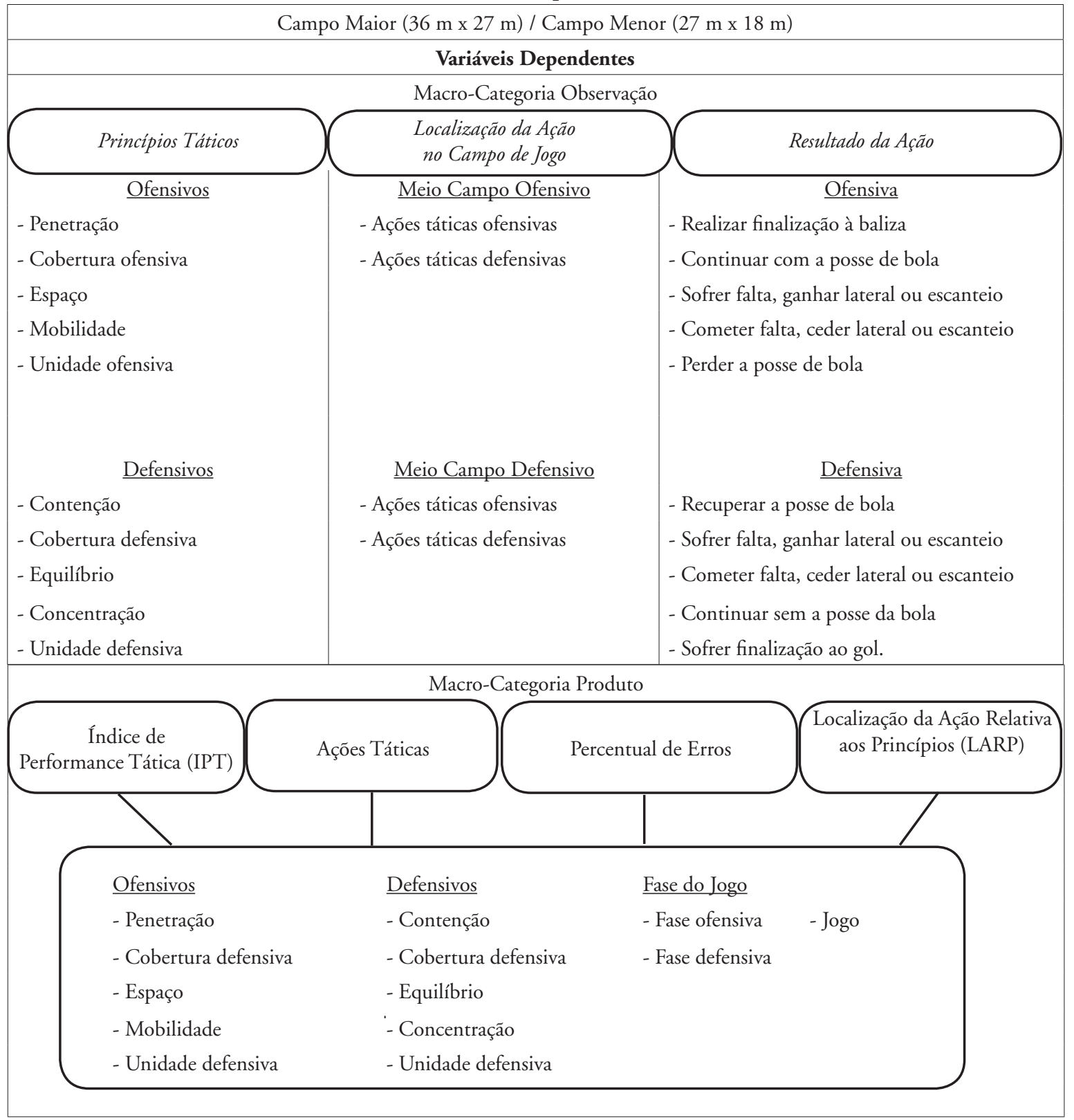

FIGURA 1 - Variáveis e macro-categorias do sistema de análise tática no futebol (FUT-SAT).

\section{Procedimentos de coleta de dados}

A coleta de dados foi realizada em dois clubes portugueses, com o consentimento dos seus responsáveis. A escolha destes dois clubes decorrem pelo fato de possuírem equipes com níveis de desempenho semelhantes que disputam campeonatos regionais da categoria sub-15. Em cada clube foram formadas duas equipes e os atletas receberam informaçôes sobre o objetivo do teste. Todos os jogadores tinham os seus coletes numerados de modo a facilitar a respectiva identificação. Concedeu-se aos jogadores 30 segundos de "familiarização", findos os quais se deu início ao teste.

\section{Instrumento de coleta e análise dos dados}

\section{Caracterização do teste}

O instrumento utilizado no presente estudo foi o Teste "GR3-3GR", desenvolvido no Centro de Estudos dos Jogos Desportivos da Faculdade de Desporto da Universidade do Porto (COSTA et al., 2009a). O teste "GR3-3GR" é aplicado em um campo de 36 metros de comprimento por 27 metros de largura, durante quatro minutos de jogo. As dimensões do terreno usadas neste teste foram calculadas com base 
nas medidas do campo de Futebol preconizadas pela International Football Association Board e no cálculo de proporção ${ }^{1}$ entre o espaço de jogo e o número de jogadores de linha (FIFA, 2008). O teste foi aplicado em campos com duas dimensōes diferentes, no sentido de averiguar de que modo os comportamentos táticos dos jogadores variavam perante a alteração das respectivas dimensões. Assim os campos utilizados foram: Campo Maior: 36 metros de comprimento por 27 metros de largura; e Campo Menor ${ }^{2}: 27$ metros de comprimento por 18 metros de largura.

A quantidade de tempo foi estabelecida através de um estudo piloto, no qual se verificou que quatro minutos, comparativamente com o tempo de duração até oito minutos, seriam suficientes para que todos os jogadores realizassem ações relacionadas com todos os princípios táticos a serem avaliados pelo instrumento de observação (CostA et al., 2009b).

Para a realização do teste, os praticantes foram divididos aleatoriamente em duas equipes de três jogadores e goleiro cada, com coletes numerados de um a seis. Cada equipe possuiu coletes de cor diferente, sendo numerados de um a três para uma cor e de quatro a seis para outra, com objetivo de facilitar a identificação dos jogadores no vídeo. Durante a aplicação foi solicitado aos jogadores que jogassem de acordo com as regras oficiais do jogo, com exceção da regra do "fora de jogo". As imagens foram gravadas por uma câmera de vídeo colocada em diagonal em relação às linhas de fundo e lateral.

A configuração numérica $\mathrm{GR}+3$ vs. $3+\mathrm{GR}$ (goleiro +3 jogadores vs. 3 jogadores + goleiro) utilizada no teste garantiu a ocorrência de todos os princípios táticos inerentes ao jogo formal $(11 \times 11)$ pelo fato de permitir, em termos ofensivos, passar de uma escolha binária a uma escolha múltipla e preservar a noção de jogo sem bola, uma vez que reúne o portador da bola e dois recebedores potenciais. Do ponto de vista defensivo, reúne um defensor direto ao portador da bola ( $1^{\circ}$ def.), para realizar a contenção, e dois defensores $\left(2^{\circ}\right.$ e $\left.3^{\circ}\right)$ relativamente mais afastados do portador da bola, para concretizarem eventuais coberturas, dobras e compensaçôes, respeitando os outros princípios táticos defensivos (GARGANTA, 2002).

\section{Materias para coleta e tratamento das imagens}

Para a gravação dos jogos foi utilizada uma câmara digital PANASONIC modelo NV - DS35EG. O material de vídeo obtido foi introduzido em formato digital em um computador portátil (marca LG modelo E500 processador Intel T2370) via cabo (IEEE 1394) convertendo-os em ficheiros "avi".
Para o tratamento de imagem e análise do jogo foram utilizados os "softwares" Utilius VS® e Soccer Analyser ${ }^{\circledR}$. O primeiro destina-se ao registro e arquivo das ações observadas. O segundo, construído especificamente para o Teste "GR3-3GR", permite inserir as referências espaciais do teste no vídeo e possibilita a avaliação rigorosa do posicionamento e da movimentação dos jogadores no campo de jogo.

\section{Protocolo do teste "GR3-3GR"}

O primeiro procedimento consiste em observar e analisar as açôes realizadas pelo jogador durante a partida. A unidade de observação e análise é a posse de bola. A posse de bola é considerada quando um jogador respeita, pelo menos, um dos seguintes pressupostos: a) realiza pelo menos três contatos consecutivos com a bola; b) executa um passe positivo (permite à equipe manter a posse de bola); c) realiza um remate (finalização).

O segundo procedimento refere-se à avaliação, classificação e registro das ações táticas. Para realizar estas três ações o avaliador baseia-se no instrumento de observação do teste e tem o auxílio dos "softwares" Soccer Analyser® e Utilius VS®. O primeiro, construído especificamente para esse sistema, permite inserir as referências espaciais no vídeo e possibilita a avaliação rigorosa do posicionamento e da movimentação dos jogadores no campo de jogo. $\mathrm{O}$ segundo destina-se ao registro e arquivo das ações observadas.

$\mathrm{O}$ último procedimento refere-se ao cálculo das variáveis que integram as categorias IPT, Açōes Táticas, Percentual de Erros e LARP. Para automatizar esse procedimento foi construída uma planilha "ad hoc" no programa Excel for Windows ${ }^{\circledR}$ (vide FIGURA 2). Essa planilha permite, a partir da inserção dos registros feitos no segundo procedimento, realizar automaticamente o cálculo das variáveis dessas quatro categorias.

Destas categorias, a IPT se caracteriza pelas suas variáveis serem de cunho composto. Os cálculos das suas variáveis são feitos com base no critério de realização do princípio tático por parte do jogador e nas três categorias de variáveis que compõem a Macro-categoria Observação. A partir disso realiza-se os cálculos para os índices de jogo, da fase ofensiva, da fase defensiva e de cada princípio. Os valores de ponderação das variáveis utilizados para esses cálculos estão expostos no QUADRO 1 e as suas combinaçōes fornecem valores que variam entre zero e 100 pontos. A equação utilizada para os cálculos é: 
Índice de Performance Tática $(\mathrm{IPT})=\sum$ ações táticas ${ }_{(\mathrm{RP} \times \mathrm{QR} \times \mathrm{LA} \times \mathrm{RA})} /$ número de ações táticas

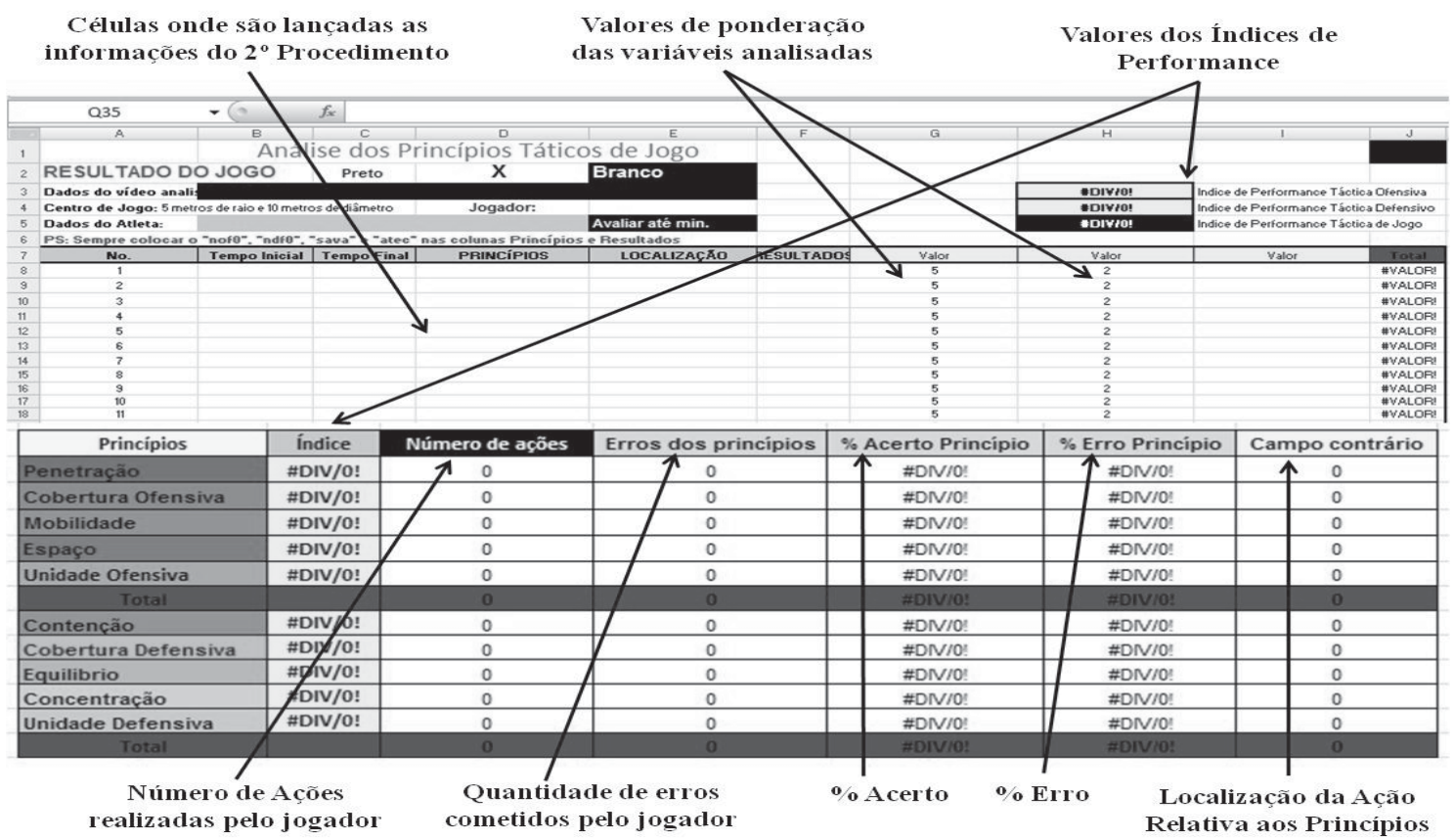

FIGURA 2 - Planilha Excel "ad hoc" que permite realizar automaticamente cálculos das variáveis das categorias IPT, Ações Táticas, Percentual de Erros e LARP.

QUADRO 1 - Componentes e valores considerados para o cálculo do Índice de Performance Tática.

\begin{tabular}{|c|c|c|c|}
\hline Componentes & Valores & & Valores \\
\hline \multicolumn{4}{|l|}{ 1) Realização do Princípio (RP) } \\
\hline Fez & 1 & & \\
\hline Não fez & 0 & & \\
\hline \multicolumn{4}{|l|}{ 2) Qualidade de Realização do Princípio (QR) } \\
\hline Bem sucedido & 10 & & \\
\hline Mal sucedido & 5 & & \\
\hline \multicolumn{4}{|l|}{ 3) Localização da Ação no Campo de Jogo (LA) } \\
\hline - Meio Campo Ofensivo & & - Meio Campo Defensivo & \\
\hline Ações Táticas Ofensivas & 2 & Ações Táticas Defensivas & 2 \\
\hline Ações Táticas Defensivas & 1 & Ações Táticas Ofensivas & 1 \\
\hline \multicolumn{4}{|l|}{ 4) Resultado da Ação (RA) } \\
\hline - Ofensiva & & - Defensiva & \\
\hline Realizar finalização ao gol & 5 & Recuperar a posse de bola & 5 \\
\hline Continuar com a posse de bola & 4 & Sofrer falta, ganhar lateral ou escanteio & 4 \\
\hline Sofrer falta, ganhar lateral ou escanteio & 3 & Cometer falta, ceder lateral ou escanteio & 3 \\
\hline Cometer falta, ceder lateral ou escanteio & 2 & Continuar sem a posse de bola & 2 \\
\hline Perder a posse de bola & 1 & Sofrer finalização ao gol & 1 \\
\hline
\end{tabular}




\section{Instrumento de observação do teste "GR3-3GR"}

O instrumento de observação do Teste "GR33GR" permite analisar, avaliar e classificar as ações táticas desempenhadas pelos jogadores com e sem bola em função das variáveis contidas nas categorias: Princípios Táticos, Localização da Ação no Campo de Jogo e Resultado da Ação.

As variáveis destas três categorias foram inicialmente concebidas através de consulta na literatura (BOUTHIER, 2001; Castelo, 1996; Garganta, 1997; Garganta \& Pinto, 1994; Gréhaigne, Godbout, Memmert \& Harvey, 2008; Oslin, Mitchell \& Griffin, 1998; TeOdorescu, 1984; Worthington, 1974). O objetivo foi identificar quais princípios táticos, quais espaços de jogo e quais resultados deveriam ser considerados na avaliação da performance tática do jogador. A partir dessa constatação procedeu-se à formulação das definições, à categorização e à criação de códigos para cada uma dessas variáveis ${ }^{3}$. As categorias, as subcategorias, as variáveis, as definiçôes e os códigos que são utilizados no instrumento de observação do Teste "GR3-3GR" podem ser consultados no ANEXO I.

As ações táticas que caracterizam cada princípio também foram identificadas com base na literatura referida no parágrafo anterior. O objetivo consistiu em verificar quais ações táticas poderiam ser observáveis em jogo a partir da movimentação dos jogadores. A partir desse procedimento foi possível referenciar as ações táticas e os seus indicadores de performance. Também foi possível estabelecer as referências espaciais de cada um dos princípios. O QUADRO 2 mostra as referências espaciais, as ações táticas e os indicadores de performance de cada princípio presentes no instrumento de observação do Teste "GR3-3GR". As referências espaciais baseiam-se nos conceitos de campograma ${ }^{4}$, epicentro de jogo ${ }^{5}$, linha da bola ${ }^{6}$ e centro de jogo ${ }^{7}$.

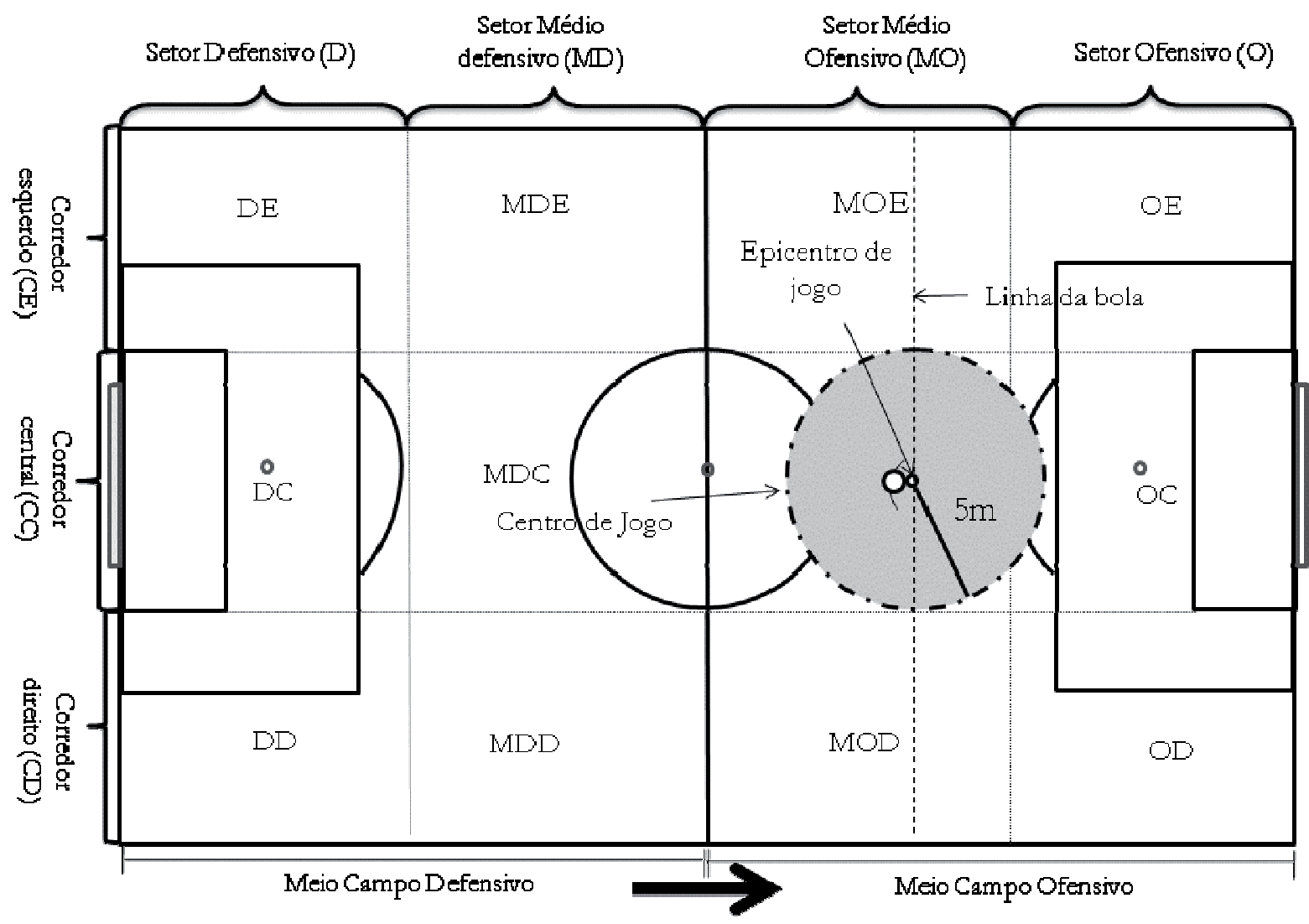

FIGURA 3 - Referências espaciais utilizadas para avaliação das ações táticas e para os indicadores de performance de cada princípio tático presente no instrumento de observação do Teste "GR3-3GR". 
QUADRO 2 - Variáveis, referências espaciais, ações táticas e indicadores de performance do Instrumento de Observação do Teste “GR3-3GR”.

\begin{tabular}{|c|c|c|c|}
\hline Variáveis & Referências Espaciais & Açôes Táticas & Indicadores de Performance* \\
\hline Penetração & $\begin{array}{l}\text { Progressões do portador da bola } \\
\text { em direção à baliza ou à linha de } \\
\text { fundo adversária. }\end{array}$ & $\begin{array}{l}\text { Condução da bola pelo espaço dis- } \\
\text { ponível (com ou sem defensores à } \\
\text { frente). } \\
\text { Realização de dribles que colocam } \\
\text { a equipe em superioridade numéri- } \\
\text { ca em ações de ataque. } \\
\text { Condução de bola em direção à li- } \\
\text { nha de fundo ou ao gol adversário. } \\
\text { Realização de dribles que propi- } \\
\text { ciam condiçóes favoráveis a um } \\
\text { passe/assistência para o compa- } \\
\text { nheiro dar sequência ao jogo. }\end{array}$ & $\begin{array}{l}\text { Bem sucedida }(+) \\
\text { Propiciar remate, passe ou drible. } \\
\text { Mal sucedida }(-) \\
\begin{array}{l}\text { Permitir o desarme adversário / Di- } \\
\text { rigir jogo espaço ocupado. }\end{array}\end{array}$ \\
\hline $\begin{array}{l}\text { Cobertura } \\
\text { Ofensiva }\end{array}$ & $\begin{array}{l}\text { Apoios ofensivos realizados: } \\
\text {-Dentro do centro de jogo; } \\
\text {-Fora do centro de jogo, na região } \\
\text { demarcada pelo limite da metade } \\
\text { menos ofensiva do centro de jogo e } \\
\text { o corredor subsequente do sentido } \\
\text { de jogo. }\end{array}$ & $\begin{array}{l}\text { Disponibilização de linhas de passe } \\
\text { ao portador da bola. } \\
\text { Apoios próximos ao portador da } \\
\text { bola que permitem manter a posse } \\
\text { de bola. } \\
\text { Realização de tabelas e/ou trian- } \\
\text { gulaçôes com o portador da bola. } \\
\text { Apoios próximos ao portador da } \\
\text { bola que permitem assegurar supe- } \\
\text { rioridade numérica ofensiva. }\end{array}$ & $\begin{array}{l}\text { Bem sucedida (+) } \\
\text { Garantir linha de passe / Reduzir } \\
\text { pressão portador / Permite possibi- } \\
\text { lidade de remate. } \\
\text { Mal sucedida (-) } \\
\begin{array}{l}\text { Não garantir linha de passe / Não } \\
\text { reduzir pressão portador / Não } \\
\text { permite possibilidade de remate. }\end{array}\end{array}$ \\
\hline Mobilidade & $\begin{array}{l}\text { Movimentaçôes executadas entre a } \\
\text { linha do último defensor e a baliza } \\
\text { ou a linha de fundo adversária. }\end{array}$ & $\begin{array}{l}\text { Movimentações em profundidade } \\
\text { ou em largura, "nas costas" do últi- } \\
\text { mo defensor em direção a linha de } \\
\text { fundo ou ao gol adversário. } \\
\text { Movimentações em profundidade } \\
\text { ou em largura, "nas costas" do úl- } \\
\text { timo defensor que visem ganho de } \\
\text { espaço ofensivo. } \\
\text { Movimentaçóes em profundidade } \\
\text { ou em largura, "nas costas" do úl- } \\
\text { timo defensor que propiciem rece- } \\
\text { ber a bola. } \\
\text { Movimentaçôes em profundidade } \\
\text { ou em largura, "nas costas" do úl- } \\
\text { timo defensor que visem a criação } \\
\text { de oportunidades para a sequência } \\
\text { ofensiva do jogo. }\end{array}$ & $\begin{array}{l}\text { Bem sucedida }(+) \\
\text { Possibilitar passe profundidade } \\
\text { para colega / Amplia EJE nas cos- } \\
\text { tas da defesa } \\
\text { Mal sucedida }(-) \\
\begin{array}{l}\text { Não possibilitar passe profundi- } \\
\text { dade para colega / Jogador fica em } \\
\text { impedimento }\end{array}\end{array}$ \\
\hline Espaço & $\begin{array}{l}\text { Movimentaçôes realizadas fora do } \\
\text { centro de jogo, entre a linha da } \\
\text { bola e a linha do último defensor. } \\
\text { Movimentações do portador da } \\
\text { bola realizadas em direção à linha } \\
\text { lateral ou à própria baliza. }\end{array}$ & $\begin{array}{l}\text { Busca por espaços não ocupados } \\
\text { pelos adversários no campo de } \\
\text { jogo. } \\
\text { Movimentações de ampliação do } \\
\text { espaço de jogo que proporcionam } \\
\text { superioridade numérica no ataque. } \\
\text { Drible ou condução para trás/linha } \\
\text { lateral que permitem diminuir a } \\
\text { pressão adversária sobre a bola. } \\
\text { Movimentações que permitem (re) } \\
\text { iniciar o processo ofensivo em zo- } \\
\text { nas distantes daquela onde ocorreu } \\
\text { a recuperação da posse de bola. }\end{array}$ & 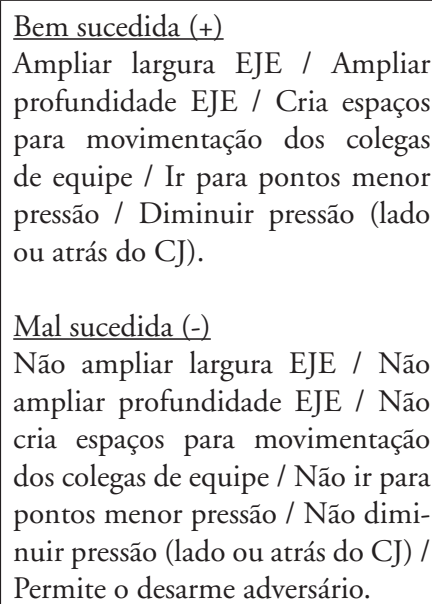 \\
\hline
\end{tabular}

*As descrições dos indicadores de performance não foram colocadas nesse quadro devido à escassez espaço. 
QUADRO 2 - Variáveis, referências espaciais, ações táticas e indicadores de performance do Instrumento de Observação do Teste “GR3-3GR” (continuação).

*As descrições dos indicadores de performance não foram colocadas nesse quadro devido à escassez espaço.

\begin{tabular}{|c|c|c|c|}
\hline Variáveis & Referências Espaciais & Açôes Táticas & Indicadores de Performance* \\
\hline $\begin{array}{l}\text { Unidade } \\
\text { Ofensiva }\end{array}$ & $\begin{array}{l}\text { Movimentações de apoio ofensivo } \\
\text { realizadas fora do centro de jogo, } \\
\text { tendo como referência: } \\
\text {-O limite da metade menos ofen- } \\
\text { siva do centro de jogo e a própria } \\
\text { baliza; } \\
\text {-O limite da metade menos ofensi- } \\
\text { va do centro de jogo e a linha late- } \\
\text { ral oposta ao sentido de jogo; } \\
\text {-O corredor oposto ao de localiza- } \\
\text { ção da metade menos ofensiva do } \\
\text { centro de jogo. }\end{array}$ & $\begin{array}{l}\text { Avanço da última linha de defesa per- } \\
\text { mitindo que a equipe jogue em bloco. } \\
\text { Saída da linha de defesa dos setores } \\
\text { defensivos e aproximação da mes- } \\
\text { ma à linha de meio-campo. } \\
\text { Avanço dos jogadores da defesa pro- } \\
\text { piciando que mais companheiros par- } \\
\text { ticipem das ações no centro de jogo. } \\
\text { Movimentação dos laterais em di- } \\
\text { reção ao corredor central quando } \\
\text { as ações do jogo são desenvolvidas } \\
\text { no lado oposto. }\end{array}$ & $\begin{array}{l}\text { Bem sucedida }(+) \\
\text { Aproximar equipe ao CJ / Partici- } \\
\text { par ação subsequente / Contribuir } \\
\text { atrás linha da bola / Auxiliar equi- } \\
\text { pe avançar ao MCO } \\
\text { Mal sucedida (-) } \\
\begin{array}{l}\text { Não aproximar equipe ao CJ / Não } \\
\text { participar ação subsequente / Não } \\
\text { contribuir atrás linha da bola / Não } \\
\text { auxiliar equipe avançar ao COM. }\end{array}\end{array}$ \\
\hline Contenção & $\begin{array}{l}\text { Ações de oposição do jogador de } \\
\text { defesa ao portador da bola, reali- } \\
\text { zadas entre a bola e a baliza a de- } \\
\text { fender. }\end{array}$ & $\begin{array}{l}\text { Marcação ao portador da bola, im- } \\
\text { pedindo a ação de penetração. } \\
\text { Ação de "proteção da bola" que } \\
\text { impede o adversário de alcançá-la. } \\
\text { Realização da "dobra" defensiva ao } \\
\text { portador da bola. } \\
\text { Realização de faltas técnicas para } \\
\text { conter a progressão da equipe ad- } \\
\text { versária, quando o sistema defensi- } \\
\text { vo está desorganizado. }\end{array}$ & $\begin{array}{l}\text { Bem sucedida }(+) \\
\text { Impedir o remate / Impedir pro- } \\
\text { gressão / Retardar ação oponente } \\
\text { / Direcionar p/ zonas menor risco } \\
\text { Mal sucedida (-) } \\
\begin{array}{l}\text { Não impedir o remate / Não impe- } \\
\text { dir progressão / Não retarda a ação } \\
\text { oponente / Não direcionar para } \\
\text { zonas menor risco. }\end{array}\end{array}$ \\
\hline $\begin{array}{l}\text { Cobertura } \\
\text { Defensiva }\end{array}$ & $\begin{array}{l}\text { Apoio defensivo ao jogador de con- } \\
\text { tenção realizado dentro da metade } \\
\text { mais ofensiva do centro de jogo. }\end{array}$ & $\begin{array}{l}\text { Ação de cobertura ao jogador de } \\
\text { contenção. } \\
\text { Posicionamento que permite obs- } \\
\text { truir eventuais linhas de passe para } \\
\text { jogadores adversários. } \\
\text { Marcação de adversário(s) que } \\
\text { pode(m) receber a bola em situaçôes } \\
\text { vantajosas para o ataque. } \\
\text { Posicionamento adequado que permi- } \\
\text { te marcar o portador da bola quando } \\
\text { o jogador de contenção for driblado. }\end{array}$ & $\begin{array}{l}\text { Bem sucedida }(+) \\
\text { Posicionar entre contenção ou a } \\
\text { baliza / Possibilitar } 2^{\text {a }} \text { contenção / } \\
\text { Obstruir linhas de passe } \\
\text { Mal sucedida (-) } \\
\text { Não posicionar entre contenção } \\
\text { ou a baliza / Não possibilitar 2a } \\
\text { contenção / Não obstruir linhas de } \\
\text { passe. }\end{array}$ \\
\hline Equilíbrio & $\begin{array}{l}\text { Movimentações de estabilidade na } \\
\text { relação de oposição realizadas: } \\
\text {-Na(s) zona(s) lateral(is) à zona de } \\
\text { localização da metade mais ofensiva } \\
\text { do centro de jogo, delimitada pela } \\
\text { linha da bola e o setor subsequente; } \\
\text { - Na metade menos ofensiva do } \\
\text { centro de jogo. }\end{array}$ & $\begin{array}{l}\text { Movimentações que permitem as- } \\
\text { segurar estabilidade defensiva. } \\
\text { Movimentação de recuperação de- } \\
\text { fensiva feita por trás do portador } \\
\text { da bola. } \\
\text { Posicionamento que permite obs- } \\
\text { truir eventuais linhas de passe longo. } \\
\text { Marcação de jogadores adversários } \\
\text { que apoiam as ações ofensivas do } \\
\text { portador da bola. }\end{array}$ & $\begin{array}{l}\text { Bem sucedida (+) } \\
\text { Estabilizar zonas laterais CJ / Obs- } \\
\text { truir linhas de passe / Estabilizar } \\
\text { M-OCJ / Interferir no portador } \\
\text { M-OCJ / Obstruir linhas de passe. } \\
\text { Mal sucedida (-) } \\
\text { Não estabilizar zonas laterais CJ / Não } \\
\text { obstruir linhas de passe / Não estabili- } \\
\text { zar M-OCJ / Não interferir portador } \\
\text { M-OCJ / Não obstruir linhas de passe. }\end{array}$ \\
\hline Concentração & $\begin{array}{l}\text { Movimentaçóes de reforço defensi- } \\
\text { vo na zona do campo onde se en- } \\
\text { contra a metade mais ofensiva do } \\
\text { centro do jogo. }\end{array}$ & $\begin{array}{l}\text { Movimentação que propicia re- } \\
\text { forço defensivo na zona de maior } \\
\text { perigo para a equipe. } \\
\text { Marcação de jogadores adversários } \\
\text { que buscam aumentar o espaço de } \\
\text { jogo ofensivo. } \\
\text { Movimentações que propiciam } \\
\text { aumento do número de jogadores } \\
\text { entre a bola e o gol. } \\
\text { Movimentações que condicionam as } \\
\text { ações de ataque da equipe adversária } \\
\text { para as extremidades do campo de jogo. }\end{array}$ & $\begin{array}{l}\text { Bem sucedida }(+) \\
\text { Diminuir profundidade adversária } \\
\text { / Direcionar zonas de menor risco } \\
\text { Mal sucedida }(-) \\
\text { Não diminuir profundidade ad- } \\
\text { versária / Não direcionar zonas de } \\
\text { menor risco. }\end{array}$ \\
\hline
\end{tabular}

Continua 
QUADRO 2 - Variáveis, referências espaciais, ações táticas e indicadores de performance do Instrumento de Observação do Teste “GR3-3GR” (continuação).

\begin{tabular}{|c|c|c|c|}
\hline Variáveis & Referências Espaciais & Açôes Táticas & Indicadores de Performance* \\
\hline $\begin{array}{l}\text { Unidade } \\
\text { Defensiva }\end{array}$ & $\begin{array}{l}\text { Movimentações de apoio defensivo } \\
\text { realizadas: } \\
\text {-Fora do centro do jogo, tendo } \\
\text { como referência: a linha da bola e a } \\
\text { baliza adversária; } \\
\text {-No(s) setor(es) subsequente(s) à } \\
\text { zona de localização da metade mais } \\
\text { ofensiva do centro do jogo e a bali- } \\
\text { za a defender; } \\
\text {-No corredor oposto à zona de lo- } \\
\text { calização da metade mais ofensiva } \\
\text { do centro do jogo. }\end{array}$ & $\begin{array}{l}\text { Organização dos posicionamentos } \\
\text { após perda da posse de bola, com } \\
\text { o objetivo de reorganizar as linhas } \\
\text { de defesa. } \\
\text { Movimentação dos laterais em di- } \\
\text { reção ao corredor central quando } \\
\text { as ações do jogo são desenvolvidas } \\
\text { no lado oposto. } \\
\text { Compactação defensiva da equipe } \\
\text { na zona que representa perigo. } \\
\text { Movimentação dos jogadores que } \\
\text { compõem as linhas transversais de } \\
\text { defesa de forma a reduzir o campo } \\
\text { de jogo do adversário (utilizando } \\
\text { o recurso da lei do impedimento). }\end{array}$ & $\begin{array}{l}\text { Bem sucedida }(+) \\
\text { Diminuir amplitude adversária / } \\
\text { (Re)equilibrar a organização de- } \\
\text { fensiva / Contribuir atrás linha da } \\
\text { bola / Aproximar equipe ao CJ / } \\
\text { Participar ação subsequente } \\
\text { Mal sucedida (-) } \\
\text { Não diminuir amplitude adversá- } \\
\text { ria / Não (re)equilibrar a organi- } \\
\text { zação defensiva / Não contribuir } \\
\text { atrás linha da bola / Não aproxi- } \\
\text { mar equipe ao CJ / Não participar } \\
\text { ação subsequente. }\end{array}$ \\
\hline
\end{tabular}

\section{Validade de conteúdo do instrumento de observação do teste "GR3-3GR"}

A validade de conteúdo do instrumento de observação do Teste "GR3-3GR" foi realizada por um painel de sete peritos (CrOnBACH, 1988). A seleção desses peritos foi baseada em quatro critérios vinculados às experiências prática e acadêmica no Futebol. Para cumprir esses requisitos os peritos deveriam ter trabalhado em comissões técnicas nas categorias de base e em equipes profissionais. Adicionalmente, deveriam possuir curso de treinadores, mínimo nível II, e ter grau acadêmico relacionado com a área do Futebol. Ao cumprir esses critérios o painel de peritos ficou composto por cinco mestres e dois doutores em Ciências do Esporte, sendo que todos eles já haviam participado com equipes profissionais de competiçóes nacionais, Taça UEFA, Liga dos Campeões Europeus ou eliminatórias para a Copa do Mundo de Seleções.

A este painel de peritos solicitou-se a opinião sobre a pertinência das variáveis que compõem o instrumento de observação do Teste "GR3-3GR", considerando a sua representatividade em relação aos aspectos fundamentais do jogo. Assim, eles opinaram a respeito do conteúdo das categorias Princípios Táticos, Localização da Ação no Campo de Jogo e Resultado da Ação, analisando: a) a importância e a definição das variáveis; b) a ponderação das variáveis e das categorias para a performance tática; c) as referências espaciais utilizadas nas definições dos princípios táticos; e d) as ações táticas e os seus indicadores de performance.

Todas as frases que suscitaram dúvidas sobre a semântica foram reformuladas até se obter o consenso dos peritos. Somente após a análise dos aspectos mencionados no parágrafo anterior e a aprovação unânime dos peritos se considerou uma variável válida para incorporar o instrumento de observação do Teste "GR3-3GR".

\section{Procedimentos de análise de dados}

Para a análise dos dados foi utilizado o "software" SPSS (Statistical Package for Social Science) for Windows $®$, versão 17.0. Foram realizadas análises de frequência, percentual e variação percentual para as variáveis das categorias Princípios Táticos, Localização da Ação no Campo de Jogo e Resultado da Ação e média e desvio padrão para as variáveis das categorias IPT, Açôes Táticas, Percentual de Erros e LARP.

O teste de Shapiro-Wilk foi utilizado para verificar a normalidade de distribuição dos dados. Utilizou-se o teste qui-quadrado $\left(\chi^{2}\right)$, com um nível de significância de $\mathrm{p} \leq 0,05$ para comparar as frequências das variáveis pertencentes as categorias Princípios Táticos, Localização da Ação no Campo de Jogo e Resultado da Ação; e o teste de Mann-Whitney $U(p \leq 0,05)$ para comparar as médias das variáveis pertencentes as categorias IPT, Açôes Táticas, Percentual de Erros e LARP entre o Campo Maior e o Campo Menor.

\section{Análise da confiabilidade das observações}

Para efeitos de aferição da confiabilidade das observaçōes, foram consideradas 246 ações táticas, representando $16,67 \%$ da amostra; valor superior ao de referência $(10 \%)$ apontado pela literatura (TABaChNick \& Fidell, 2001). As sessões para determinar a fidedgnidade foram realizadas respeitando um intervalo de três semanas para evitar problemas de familiaridade com a tarefa (ROBINSON \& O’Donoghue, 2007). Os resultados de Kappa 
para as confiabilidades intra e inter-observadores foram, respectivamente, 0,97 (erro padrão 0,02) e
0,87 (erro padrão 0,03), sendo classificadas como “perfeitas” pela literatura (LANDIS \& KoCH, 1977).

\section{Resultados}

\section{Macro-categoria observação}

Os resultados serão apresentados em função das macro-categorias de variáveis dependentes do estudo. Desta forma, serão primeiramente mencionados os resultados das categorias Princípios Táticos, Localização da Ação no Campo de Jogo e Resultado da Ação; e, posteriormente, os resultados das categorias IPT, Açôes Táticas, Percentual de Erros e LARP.

A TABELA 1 apresenta as frequências, os percentuais e as variaçôes percentuais das variáveis das categorias Princípios Táticos, Localização da Ação no Campo de Jogo e Resultado da Ação para a prática do jogo no Campo Menor e no Campo Maior. Das 24 variáveis apresentadas na tabela, 13 apresentaram diferenças significativas entre os comportamentos realizados nos dois campos considerados.

Em referência ao total de ações táticas realizadas pelos jogadores contata-se que a prática do jogo no Campo Menor permitiu aos jogadores executarem significativamente mais ações táticas que os jogadores do Campo Maior ( $\mathrm{p}<0,001$ ).

Em relação às variáveis da categoria Princípios Táticos verifica-se que em cinco dos 10 princípios os comportamentos táticos desempenhados foram diferentes em função do jogo praticado nos dois campos. Dentre estes cinco, contata-se maior ocorrência de ações táticas no Campo Menor relacionadas com os princípios "espaço", "cobertura defensiva", "concentração" e "unidade defensiva", enquanto que no Campo Maior são, predominantemente, as ações táticas relacionadas com o princípio "equilíbrio".

No que concerne às variáveis da categoria Localização da Ação no Campo de Jogo verifica-se que a organização tática ofensiva das equipes não se alterou em função dos dois campos de jogo. Tanto na prática do jogo no Campo Menor quanto no Campo Maior os jogadores realizaram mais ações ofensivas no meio campo defensivo. Já em relação à organização tática defensiva, verificou-se que no Campo Maior as equipes escolheram fazer uma marcação em bloco alto, enquanto que no Campo Menor as equipes optaram pela marcação em bloco baixo.

$\mathrm{Na}$ categoria Resultado da Ação as diferenças significativas ocorreram em cinco das 10 variáveis que compõem a categoria. Para a fase ofensiva as diferenças se situaram nas variáveis "Sofrer falta, ganhar lateral ou escanteio" e "Perder a posse de bola"; e para a fase defensiva nas variáveis "Recuperar a posse de bola", "Cometer falta, ceder lateral ou escanteio" e "Continuar sem a posse de bola".

\section{Macro-categoria produto}

A TABELA 2 apresenta as médias e os desvios padrōes das variáveis das categorias IPT, Açōes Táticas, Percentual de Erros e $L A R P$ para a prática do jogo no Campo Menor e no Campo Maior. Das 52 variáveis apresentadas na tabela, 13 apresentaram diferenças significativas em consideração aos dois campos de jogo.

Em relação aos IPT's verificaram-se três diferenças significativas entre as variáveis dessa categoria, sendo que todas elas se referem aos aspectos defensivos. As diferenças se situaram nos princípios "concentração" e "unidade defensiva" e na "fase defensiva", sendo que as médias dessas variáveis foram superiores para os jogadores do Campo Menor.

Em referência as variáveis da categoria Ações Táticas verificou-se cinco diferenças significativas. Essas diferenças se situam nos princípios "cobertura defensiva" e "concentração", nas fases "ofensiva" e "defensiva", e no próprio "jogo". Ao analisar estas diferenças constata-se que todas as médias se apresentaram superior para o campo de menor dimensão, o que permite constatar que a prática do jogo no Campo Maior influencia não só a ocorrência de ações táticas no jogo e nas suas duas fases, como também de açôes relacionadas a esses princípios táticos defensivos.

No que diz respeito às variáveis da categoria Percentual de Erros quatro variáveis apresentaram diferenças significativas. A partir delas pode-se verificar que os jogadores do Campo Menor apresentaram mais erros na realização de ações táticas relacionadas ao princípio "cobertura defensiva" e os jogadores do Campo Maior cometeram mais erros nas açōes táticas relacionadas aos princípios da "unidade defensiva". Em função das fases de jogo, os jogadores do Campo Maior cometeram mais erros em ações táticas na fase ofensiva, apesar de disporem de mais espaço físico para construírem as suas jogadas. Na variável "jogo" também se verifica que a prática do jogo no Campo 
Maior implicou a ocorrência de maior número de erros por parte dos jogadores.

$\mathrm{Na}$ categoria $L A R P$ verificou-se que apenas a variável "cobertura defensiva" apresentou diferença significativa entre as duas dimensões de campo de jogo utilizadas. Por meio desse resultado é possível afirmar que as dimensões do campo de jogo não afetam a realização de ações táticas relacionadas aos princípios táticos de jogo, exceto para o princípio da cobertura defensiva.

TABELA 1 - Frequências, porcentagens e variações percentuais das variáveis das categorias Princípios Táticos, Localização da Ação no Campo de J ogo e Resultado da Ação no Campo Menor e no Campo Maior.

\begin{tabular}{cccccc}
\hline & Campo Menor & \multicolumn{2}{c}{ Campo Maior } & Variação Percentual** $^{*}$ Categorias e Variáveis \\
& $\mathrm{N}$ & $\%$ & $\mathrm{~N}$ & $\%$ & N $^{*}$
\end{tabular}

\section{PRINCÍPIOS TÁTICOS}

Ofensivo

$\begin{array}{lccccc}\text { Penetração } & 32 & 3,94 & 41 & 6,18 & 57,11 \\ \text { Cobertura Ofensiva } & 121 & 14,88 & 94 & 14,18 & -4,74 \\ \text { Espaço* } & 149 & 18,33 & 110 & 16,59 & -9,47 \\ \text { Mobilidade } & 42 & 5,17 & 30 & 4,52 & -12,41 \\ \text { Unidade Ofensiva } & 39 & 4,80 & 43 & 6,49 & 35,20 \\ \text { Defensivo } & & & & & \\ \text { Contenção } & 62 & 7,63 & 73 & 11,01 & 44,38 \\ \text { Cobertura Defensiva* } & 69 & 8,49 & 15 & 2,26 & -73,34 \\ \text { Equilíbrio* } & 44 & 5,41 & 68 & 10,26 & 89,51 \\ \text { Concentração* } & 74 & 9,10 & 45 & 6,79 & -25,43 \\ \text { Unidade Defensiva* } & 181 & 22,26 & 144 & 21,72 & -2,44\end{array}$

\section{LOCALIZAÇÃO DA AÇÃO NO CAMPO DE JOGO}

Meio Campo Ofensivo

Ações Táticas Ofensivas*

Ações Táticas Defensivas

Meio Campo Defensivo

Ações Táticas Ofensivas

Ações Táticas Defensivas*

\section{RESULTADO DA AÇÃO}

\section{Ofensiva}

Realizar finalização ao gol
Continuar com a posse de bola
Sofrer falta, ganhar lateral ou escanteio*
Cometer falta, ceder lateral ou escanteio
Perder a posse de bola*
Defensiva
Recuperar a posse de bola*
Sofrer falta, ganhar lateral ou escanteio
Cometer falta, ceder lateral ou escanteio*
Continuar sem a posse de bola*
Sofrer finalização ao gol
OTAL*

$\begin{array}{ccccc}176 & 21,65 & 124 & 18,70 & -13,61 \\ 194 & 23,86 & 181 & 27,30 & 14,41 \\ & & & & \\ 207 & 25,46 & 194 & 29,26 & 14,92 \\ 236 & 29,03 & 164 & 24,74 & -14,79\end{array}$

$\begin{array}{ccccc}23 & 2,83 & 34 & 5,13 & 81,27 \\ 255 & 31,37 & 227 & 34,24 & 9,16 \\ 24 & 2,95 & 9 & 1,36 & -54,02 \\ 20 & 2,46 & 19 & 2,87 & 16,49 \\ 61 & 7,50 & 29 & 4,37 & -41,70\end{array}$

$\begin{array}{ccccc}57 & 7,01 & 27 & 4,07 & -41,91 \\ 23 & 2,83 & 23 & 3,47 & 22,62 \\ 26 & 3,20 & 9 & 1,36 & -57,55 \\ 297 & 36,53 & 248 & 37,41 & 2,39 \\ 27 & 3,32 & 38 & 5,73 & 72,58 \\ 813 & & 663 & & \end{array}$

*Possuem diferenças estatisticamente significativas ( $p \leq 0,05)$. Princípios:

Ofensivo: Espaço ( $p$ $=0,02$ )

Defensivo: Cobertura Defensiva $(p<0,001)$ Equilíbrio ( $p=0,02)$, Concentração $(p=0,01)$ e Unidade Defensiva ( $p$ $=0,04$ ).

Localização daAção no Campo de Jogo: Meio Campo Ofensivo: Ações Táticas Ofensivas $(p<0,001)$ e Meio Campo Defensivo: Ações Táticas Defensivas $(p<0,001)$.

Resultado da Ação: Ofensiva: Sofrer falta, ganhar lateral ou escanteio $(p=0,01)$; Perder a posse de bola ( $p<$ $0,001) \mathrm{e}$

Defensiva: Recuperar a posse de bola ( $p<$ 0,001); Cometer falta, ceder lateral ou escanteio $(p<0,001)$ e Continuar sem a posse de bola $(p=0,04)$.

Total: $(p<0,001)$.

** A variação do percentual foi calculada considerando os dados do Campo Menor em comparação com os dados do Campo Maior. 


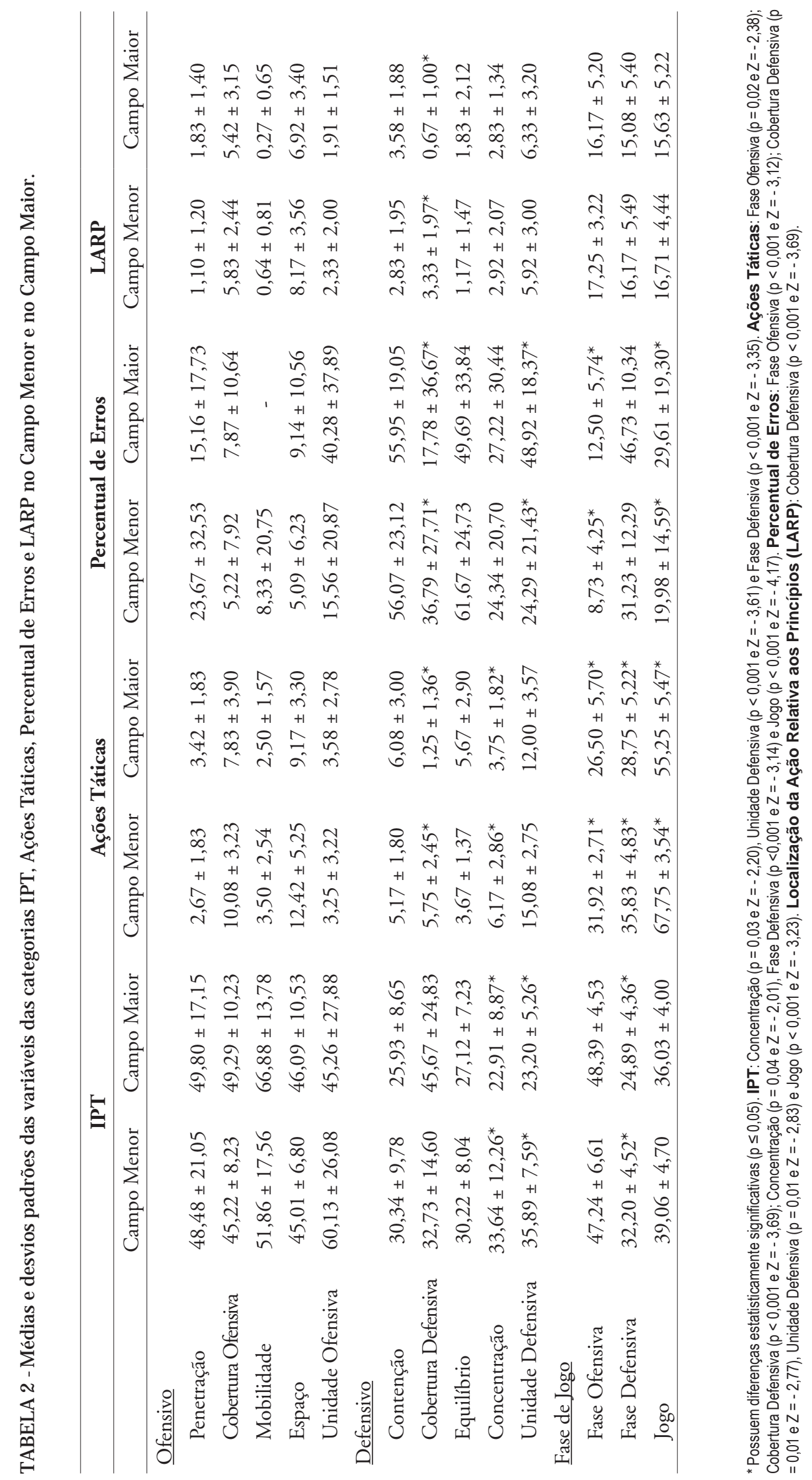

90 • Rev. bras. Educ. Fís. Esporte, São Paulo, v.25, n.1, p.79-96, jan./mar. 2011 


\section{Discussão}

Nesse estudo pretendeu-se verificar de que modo os comportamentos táticos dos jogadores de Futebol variam perante a alteração das dimensões do campo de jogo. Através dos resultados pode-se constatar que os comportamentos táticos dos jogadores de Futebol variaram em 26 das 76 variáveis analisadas. Destas diferenças, 21 obtiveram maiores valores no Campo Menor e somente cinco no Campo Maior.

O jogo praticado no campo de menor dimensão permitiu aos jogadores realizarem mais trocas de posse de bola e, consequentemente, apresentar mais dinâmica de jogo. Além disso, os comportamentos também se diferenciaram quanto ao desempenho e o percentual de erros cometidos. Constatou-se que no Campo Menor os jogadores cometeram menos erros de execução das ações relacionadas aos princípios táticos e obtiveram melhores índices de performance tática no que se refere aos aspectos defensivos de jogo. Verificou-se também que a prática do jogo no Campo Maior apresentou aos jogadores maior dificuldade para gerir o espaço de jogo e realizar com sucesso as açôes táticas relacionadas aos princípios defensivos.

A prática do Futebol nas duas dimensões também influenciou o fluxo de jogo das equipes. A partir dos resultados apresentados é possível afirmar que o jogo no Campo Menor se apresentou mais fragmentado, com mais paralisações das ações ofensivas (faltas, laterais ou escanteios), enquanto no Campo Maior as equipes tiveram maiores dificuldades para recuperar a posse de bola. O fato do jogo no Campo Menor ter se apresentado mais fragmentado pode-se pautar em três aspectos: 1) na organização defensiva; 2) no percentual de erros dos jogadores; e 3) na realização de açôes táticas relacionadas aos princípios defensivos no meio campo ofensivo.

Verificou-se também que nos dois campos de jogo os jogadores realizaram mais açôes ofensivas no meio campo defensivo, o que permite afirmar que as organizações ofensivas das equipes priorizavam a utilização desse espaço. No que refere à organização defensiva, constatou-se que os jogadores do Campo Menor realizaram mais ações de "cobertura defensi$v a$ " no campo ofensivo, provavelmente, porque a dimensão do campo propicia que os jogadores se aproximem mais do centro de jogo e realizem mais ações táticas próximas à bola. Já os jogadores do Campo Maior optaram por fazer uma marcação em bloco alto, que aumenta a pressão sobre a saída de bola do adversário. Entretanto, apresentaram dificuldades na realização de ações táticas relacionadas a três princípios defensivos: "unidade defensiva", "cobertura defensiva" e "concentração".

A realização bem sucedida de ações táticas destes três princípios é importante para que os defensores consigam retirar os espaços disponíveis para a construção das ações ofensivas do adversário (CosTA et al., 2009c). Apesar de terem realizado maior número de ações táticas do princípio "equilíbrio", essas não foram mais realizadas no campo ofensivo. Além disso, os jogadores do Campo Maior erraram mais açóes táticas de "unidade defensiva" e realizaram menos ações de "cobertura defensiva" no meio campo ofensivo.

Dentre os estudos consultados e que analisaram variáveis com essas características, verifica-se alguns deles também encontraram maior ocorrência de açôes em campos de menor dimensão (GRANT et al., 1999; Jefrreys, 2004; Jones \& Drust, 2007; Kelly \& Drust, 2009; Owen, Twist \& Ford, 2004; Panter et al., 2008; PlatT et al., 2001). Dentre estes, um corrobora os resultados de recuperação de posse de bola facilitada em função da menor dimensão do campo de jogo (Kelly \& Drust, 2009), e dois apresentam resultados contraditórios em relação à finalização à baliza (KELLY \& Drust, 2009; Platt et al., 2001), indicando que as equipes que jogaram em campo de maior dimensão tiveram mais possibilidades de finalizar ao gol.

\section{Conclusões}

Os comportamentos táticos desempenhados pelos jogadores de Futebol nos dois campos de jogo apresentaram diferenças significativas em 34,21\% das variáveis táticas analisadas. A prática do jogo no Campo Menor propiciou que os jogadores realizassem mais ações dos princípios táticos: "espaço", "cobertura defensiva" "concentração" e "unidade defensiva"; enquanto que no Campo Maior os jogadores desempenharam mais ações relacionadas ao princípio "equilibrio".

Os aspectos defensivos foram os que apresentaram maior número de diferenças entre os comportamentos desempenhados pelos jogadores nas duas dimensões de campo utilizadas; sendo que, os jogadores 
do Campo Menor tiveram melhores índices de desempenho tático nos princípios "concentração" e "unidade defensiva" e na "fase defensiva".

Os comportamentos dos jogadores na fase de construção do jogo ofensivo foram semelhantes nas duas dimensões de campo utilizadas. As equipes priorizaram a construção da fase ofensiva a partir do meio campo defensivo com trocas de bola em todo o terreno de jogo, evitando as ações de ligação direta entre a defesa e o ataque.

Em termos de gestão do espaço de jogo, constatou-se que as equipes aplicaram planos estratégicos diferentes. Enquanto que no campo de menor dimensão os jogadores optaram por fazer a marcação do adversário no campo defensivo; no Campo Maior as equipes preferiram realizar a marcação em bloco alto, pressionando o adversário na saída de bola.

Futuros estudos podem continuar a verificar as alteraçôes induzidas no comportamento dos jogadores em função da modificação das dimensões do campo de jogo. Para tal, sugere-se testar outras dimensões de campo de jogo, aumentar e diversificar a amostra quanto ao número de jogadores, ao tempo de jogo, ao tipo de piso, à idade, etc.

\section{Abstract \\ Relationship between pitch size and tactical behavior of soccer player}

The aim of this study was to examine how soccer players' tactical behavior changes according to pitch size. As such, 1,476 tactical actions performed by 12 under- 15 soccer players were analyzed. The "GK3-3GK" test was used to collect and evaluate tactical actions. This test aimed to evaluate the actions performed by players (with and without the ball) regarding ten fundamental tactical principles of Soccer game. Additionally, the test considered the place of action and the respective outcome. Based on this information thirteen performance indexes were calculated. Statistical analysis of the data was conducted using SPSS for Windows version 17.0. Descriptive analysis, Shapiro-Wilk test, chi-square test, Mann-Whitney $U$ test $(p \leq 0.05)$ and reliability test were carried out. The results showed 26 significant differences between 76 variables analyzed. Of these, 21 variables registered higher values on the smaller pitch and five variables did so on the bigger pitch. We conclude that pitch size influenced the tactical behavior performed by soccer players, particularly when related with defensive organization of the team.

UnITERMS: Soccer; Game principles; Small-sided games; Evaluation; Tactics.

\section{Notas}

1. Para esse cálculo utilizou-se a dimensão 120 metros de comprimento por 90 metros de largura, de forma a assegurar maior espaço, no campo de jogo, para a realização das ações táticas por parte dos jogadores. Estas medidas utilizadas estão previstas pela International Football Association Board (FIFA, 2008).

2. Para esse cálculo utilizou-se a dimensão 90 metros de comprimento por 60 metros de largura, conforme medidas do campo de jogo previstas pela International Football Association Board (FIFA, 2008).

3. Mais informações sobre os critérios e as variáveis avaliadas pelo Teste "GR3-3GR" podem ser obtidas no trabalho de COSTA, I.; GARGANTA, J.; GRECO, P.; MESQUITA, I. Avaliação do desempenho tático no futebol: concepção e desenvolvimento da Grelha de Observação do Teste "GR3-3GR”. Revista Mineira de Educação Física, Viçosa, v.17, n.2, p. 5-23, 2009 .

4. O campograma refere-se às linhas imaginárias traçadas sobre o campo de jogo que permitem dividi-lo em 12 zonas, três corredores e quatro setores.

5. O epicentro de jogo é o local onde a bola se encontra num determinado instante " $\mathrm{t}$ ".

6. A linha da bola é marcada transversalmente ao campo de jogo a partir do epicentro.

7. O centro de jogo é um círculo imaginário que possui cinco metros de raio do epicentro de jogo e que, em função da linha da bola, pode ser divido em metade mais ofensiva e metade menos ofensiva. 


\section{Referências}

ARAÚJO, D.; DAVIDS, K.; HRISTOVSKI, R. The ecological dynamics of decision making in sport. Psychology of Sport and Exercise, Amsterdam, v.7, n.6, p.653-76, 2006.

CASTELO, J. Futebol a organização do jogo. Lisboa: FMH Edições, 1996.

COSTA, I.; GARGANTA, J.; GRECO, P.; MESQUITA, I. Avaliação do desempenho tático no futebol: concepção e desenvolvimento da Grelha de Observação do Teste “GR3-3GR”. Revista Mineira de Educação Física, Viçosa, v.17, n.2, p.5-23, 2009a.

. Influência de tipo de piso, dimensão das balizas e tempo de jogo na aplicação do teste de "GR3-3GR" em futebol.

Lecturas, Educación Física y Deportes: Revista Digital, Buenos Aires, v.14, n.136, 2009b. Disponível em: <http://www. efdeportes.com>. Acesso em: 15 dez. 2009.

Princípios táticos do jogo de futebol: conceitos e aplicação. Revista Motriz, Rio Claro, v.15, n.3, p.657-68, 2009c. CRONBACH, L.J. Five perspectives on validity argument. In: WAINER, H.; BRAUN, H.I. (Eds.). Test validity. New Jersey: Lawrence Erlbaum, 1988. p.3-17.

FIFA. Laws of the Game 2008/2009. Zurich: Fédération Internationale de Football Association, 2008.

FRENCH, K.E.; WERNER, P.H.; RINK, J.E.; TAYLOR, K.; HUSSEY, K. The effects of a 3-week unit of tactical, skill, or combined tactical and skill instruction on badminton performance of ninth-grade students. Journal of Teaching in Physical Education, Champaign, v.15, n.4, p.418-38, 1996a.

FRENCH, K.E.; WERNER, P.H.; TAYLOR, K.; HUSSEY, K.; JONES, J. The effects of a 6-week unit of tactical, skill, or combined tactical and skill instruction on badminton performance of ninth-grade students. Journal of Teaching in Physical Education, Champaign, v.15, n.4, p.439-63, 1996b.

FRENCKEN, W.G.P.; LEMMINK, K.A. Team kinematics of small-sided soccer games. In: REILLY, T.; KORKUSUZ, F. (Eds.). Science and Football VI. London: Routledge, 2009. p.167-72. (Proceedings on the Sixth World Congress of Science and Football).

GARGANTA, J. Modelação táctica do jogo de futebol: estudo da organização da fase ofensiva em equipas de alto rendimento. 1997. 312 p. Tese (Doutorado) - Faculdade de Ciências do Desporto e de Educação Física, Universidade do Porto, Porto, 1997. Competências no ensino e treino de jovens futebolistas. Lecturas, Educación Física y Deportes: Revista Digital, Buenos Aires, v.8, n.45, 2002. Disponível em: <http://www.efdeportes.com>. Acesso em: 22 fev. 2008.

GARGANTA, J.; PINTO, J. O ensino do futebol. In: GRAÇA, A.; OLIVEIRA, J. (Eds.). O ensino dos jogos desportivos. Porto: Faculdade de Ciências do Desporto e de Educação Física/Universidade do Porto, 1994. v.1, p.95-136.

GIACOMINI, D.; GRECO, P.J. Comparação do conhecimento tático processual em jogadores de futebol de diferentes categorias e posições. Revista Portuguesa de Ciências do Desporto, Porto, v.8, n.1, p.126-36, 2008.

GRANT, A.; WILLIAMS, M.; DODD, R.; JOHNSON, S. Physiological and technical analysis of 11v11 and 8v8 youth football matches. Insight, Warwick, v.3, p.29-30, 1999.

GRANT, A.; WILLIAMS, M.; JOHNSON, S. Technical demands of 7v7 and 11v11 youth football matches. Insight, Warwick, v.4, p.26-8, 1999.

GRÉHAIGNE, J.F.; GODBOUT, P.; BOUTHIER, D. The teaching and learning of decision making in team sports. Quest, Champaign, v.53, p.59-76, 2001.

HOLT, N.L.; STREAN, W.B.; BENGOECHEA, E.G. Expanding the teaching games for understanding model: new avenues for future research and practice. Journal of Teaching in Physical Education, Champaign, v.21, p.162-76, 2002. HUGHES, M.D.; BARTLETT, R.M. The use of performance indicators in performance analysis. Journal of Sports Sciences, London, v.20, n.10, p.739-54, 2002.

JEFFREYS, I. The use of small-sided games in the metabolic training of high school soccer players. Strength \& Conditioning Journal, Champaign, v.26, n.5, p.77-8, 2004.

JONES, S.; DRUST, B. Physiological and technical demands of $4 \mathrm{v} 4$ and $8 \mathrm{v} 8$ games in elite youth soccer players. Kinesiology, Zagreb, v.39, n.2, p.150-6, 2007.

KELLY, D.M.; DRUST, B. The effect of pitch dimensions on heart rate responses and technical demands of small-sided soccer games in elite players. Journal of Science and Medicine in Sport, Belconnen, v.12, p.475-9, 2009.

LANDIS, J. R.; KOCH, G. C. The measurement of observer agreement for categorical data. Biometrics, Alexandria, v.33, p.1089-91, 1977.

LEE, M.A.; WARD, P. Generalization of tactics in tag rugby from practice to games in middle school physical education. Physical Education \& Sport Pedagogy, Worcester, v.14, n.2, p.189-207, 2009. 
McPHERSON, S. The development of sport expertise: mapping the tactical domain. Quest, Champaign, v.46, n.2, p.223-40, 1994.

MEMMERT, D.; HARVEY, S. The game performance assessment instrument (GPAI): some concerns and solutions for further development. Journal of Teaching in Physical Education, Champaign, v.27, n.2, p.220-40, 2008.

MESQUITA, I. A contextualização do treino no voleibol: a contribuição do construtivismo. In: DUARTE, A. (Ed.). O contexto da decisão: acção táctica no desporto. Lisboa: Visão e Contextos, 2005. p.355-78.

. Ensinar bem para aprender melhor o jogo de voleibol. In: TANI, G.; BENTO, J.; PETERSEN, R. (Eds.). Pedagogia do desporto. Rio de Janeiro: Guanabara Koogan, 2006. p.327-43.

MESQUITA, I.; GRAÇA, A.; GOMES, A.R.; CRUZ, C. Examining the impact of a step game approach to teaching volleyball on student tactical decision making and skill execution during game play. Journal of Human Movement Studies, London, v.48, p.469-92, 2005.

OSLIN, J.L.; MITCHELL, S.A.; GRIFFIN, L.L. The game performance assessment instrument (GPAI): development and preliminary validation. Journal of Teaching in Physical Education, Champaign, v.17, n.2, p.231-43, 1998.

OWEN, A.; TWIST, G.; FORD, P. Small-sided games: the physiological and technical effect of altering pitch size and player numbers. Insight, Warwick, v.7, n.2, p.50-3, 2004.

PANTER, A.; JOHNSTON, K.; MULLINS, C.; SATO, Y.; WELLS, C.; McAULEY, S. 'Small sided games: can they aid skill learning and development in youth players? The technical effects of altering pitch size and player numbers'. FACA Live, Warwick, p.1-6, 2008.

PÉREZ-MORALES, J.C.; GRECO, P.J. A influência de diferentes metodologias de ensino-aprendizagem-treinamento no basquetebol sobre o nível de conhecimento tático processual. Revista Brasileira de Educação Física e Esporte, São Paulo, v.21, n.4, p.291-9, 2007.

PLATT, D.; MAXWELL, A.; HORN, R.; WILLIAMS, M.; REILLY, T. Physiological and technical analysis of 3v3 and 5v5 youth football matches. Coaching, v.4, n.4, p.42-5, 2001.

ROBINSON, G.; O'DONOGHUE, P.G. A weighted kappa statistic for reliability testing in performance analysis of sport. International Journal of Performance Analysis in Sport, Cardiff, v.7, n.1, p.12-9, 2007.

TABACHNICK, B.; FIDELL, L. Using multivariate statistics. New York: Harper \& Row, 2001.

TAVARES, F. A capacidade de decisão táctica no jogador de basquetebol: estudo comparativo dos processos perceptivocognitivos em atletas seniores e cadetes. 1993. 226p. Tese (Doutorado) - Faculdade de Ciências do Desporto e de Educação Física, Universidade do Porto, Porto, 1993.

TAVARES, F.; GRECO, P.J.; GARGANTA, J. Perceber, conhecer, decidir e agir nos jogos desportivos coletivos. In: TANI, G.; BENTO, J.; PETERSEN, R. (Eds.). Pedagogia do desporto. Rio de Janeiro: Guanabara Koogan, 2006. p.284-98. TEODORESCU, L. Problemas de teoria e metodologia nos jogos desportivos. Lisboa: Livros Horizontes, 1984. TESSITORE, A.; MEEUSEN, R.; PIACENTINI, M.F.; DEMARIE, S.; CAPRANICA, L. Physiological and technical aspects of "6-a-side" soccer drills. Journal of Sports Medicine Physical Fitness, Torino, v.46, p.36-43, 2006.

WORTHINGTON, E. Learning \& teaching soccer skills. Califórnia: Hal Leighton, 1974. 


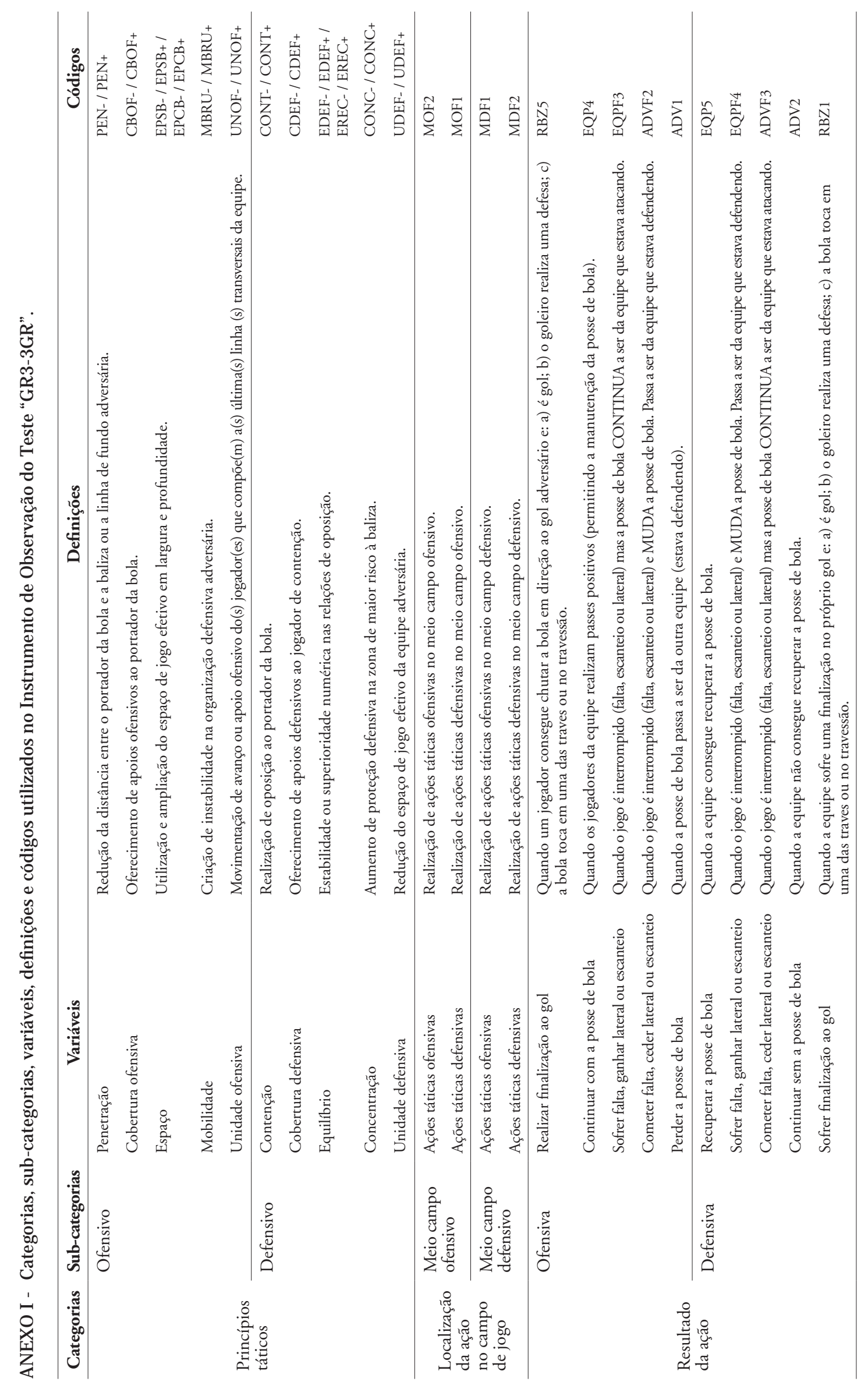

Rev. bras. Educ. Fís. Esporte, São Paulo, v.25, n.1, p.79-96, jan./mar. 2011 • 95 
COSTA, I.T. et al.

\section{Agradecimento}

Com o apoio do Programa AlBan, Programa de bolsas de alto nível da União Europeia para América Latina, bolsa $n^{\circ}$ E07D400279BR”.

Israel Teoldo da Costa

Departamento de Educação Física

Universidade Federal de Viçosa

Av. PH Rolfs, s/n - Campus Universitário

36570-000 - Viçosa - MG - BRASIL

e-mail: israel.teoldo@ufv.br
Recebido para publicação: 27/ 10/2009

1a. Revisão: $16 / 08 / 2010$

2a. Revisão: 22/09/2010

Aceito: 04/ 10/2010 